\title{
OVERTURNING THE COMMON SENSE OF CAPITALISM: \\ WHY THE OCCUPY MOVEMENT'S DIFFUSED AGENDA \\ MAY HAVE BEEN ITS GREATEST STRENGTH
}

\author{
MALISH, SHERRIE. \\ Candidate à la maîtrise en littérature canadienne comparée à l'Université de Sherbrooke
}

\begin{abstract}
Drawing on the work of David Harvey and Henry Giroux and providing examples from student protests in Québec, this article explores the reach of neoliberal thinking and ways in which an ideological and eclectic movement has been created to protest it. When spaces open up in which people begin to imagine new power relations, there is an alignment between political and educational goals as exemplified by the Occupy movements that can act to counter neo-liberal thinking. The Occupy movement, which consists to a great extent of youth who do not have class privilege, must be diffused in order to counter the undeniable successes of neo-liberal politics. The university is a prime site of the type of intellectual engagement aligned with youth interests as well as goals of diversity in thinking that can lead to social and political renewal. Given this, what the student protesters seem to be articulating is a defiance of disposability as well as the singular ideology of neoliberalism, and a fierce belief in their own right to be integral human beings and human bodies, and to flourish so that they can contribute to the body politic.
\end{abstract}

Keywords: democracy, socialism, education, anti-austerity movement, civil disobedience

Résumé: Centré sur la pensée de David Harvey et de Henry Giroux de même que sur les manifestations étudiantes au Québec, cet article explore l'apogée de la pensée néolibérale et les conditions qui ont favorisé la création d'un mouvement idéologique et éclectique afin de critiquer cette même pensée. Quand de nouveaux espaces sont créés, au sein desquels des gens commencent à imaginer de nouvelles relations de pouvoir, les visées politiques s'ajustent à celles de l'éducation, comme l'ont montré les différents mouvements Occupy, qui peuvent contrer la pensée néolibérale. Le mouvement Occupy, qui consiste en grande partie en l'affirmation de jeunes qui ne détiennent aucun privilège de classe sociale, doit être diffus afin de contrer les succès indéniables des politiques néolibérales. L'université est un lieu de prédilection pour ce type d'engagement intellectuel, qui correspond aux intérêts des jeunes tout aussi bien qu'aux buts de la diversité, ainsi que pour la diffusion d'une pensée pouvant mener à un renouveau social et politique. En supposant cela, ce que les manifestants étudiants semblent vouloir exprimer est une résistance à la notion du « jetable », du « disposable », une vision singulière du néolibéralisme, mais aussi l'intime conviction d'être des êtres ainsi que des corps humains à part entière qui ont le droit de s'épanouir, contribuant ainsi à la prospérité de l'état-nation.

Mots-clés: Démocratie, socialisme, éducation, mouvement anti-austérité, désobéissance civile 
This article evolved as a series of three interconnected think pieces drafted in response to the emergence of dual events, Occupy Wall Street (OWS) and the Student Strikes that swept through Québec in spring and summer 2012. At the time, I was reading David Harvey on the logic of neoliberalism and Henry Giroux on the concept of disposability and the promise of radical pedagogy. It seemed that, even when I was curled up reading theory, the strikes were never far away. Scenes of protest flickered across computer and television screens or sat frozen in front page photos on the kitchen table.

It is difficult, in retrospect, to capture the radical sense of possibility that began to open up in Québec as student protesters were joined by workers and supporters from all manner of social background. Radical protest in Canada had seemed to be a thing of the past. Although Québec's cultural lineage places the Paris revolts of 1968 within a sense of shared (or borrowed?) common history, on the whole daily life in Québec proceeds more and more steadily in rhythm with life in Canada's influential neighbor to the south. Then, suddenly there was Occupy Wall Street (OWS); and then the Arab Spring ; and then the Printemps érable, the Maple Spring (referred to interchangeably here with the Québec Student Strikes).

As The Atlantic pointed out at the time, OWS, the Arab Spring and the Printemps érable were substantially different movements (Garland, 2012). It was a common observation among pundits, though in most respects a fatuous one. After all, why would we expect things to be otherwise, given that these movements evolved out of such different sets of needs and demands and within such different political, economic and social contexts?

However, as The Atlantic also noted, OWS, the Arab Spring and the Québec Student Strikes did share three key features. Each began with a government action or policy perceived as an egregious overstepping. In each case, the youth protests that emerged in response swiftly morphed into broader critiques of political legitimacy and economic fairness. In each case, government attempts to quell the protests served merely to spur participation by greater numbers of citizens from more diverse constituencies, leading to "a nationwide conversation about people's shared distrust of failing institutions" (Garland, 2012: para. 1). (Though in the case of the Printemps érable the conversation was province-wide rather than nationwide.) These core commonalities allowed both protestors and observers to feel that a new mode of protest was being born, one simultaneously local in focus and global in sensibility and reach.

The three short pieces comprising this article offer separate but related meditations, each geared to a different level of social organization. The first deals with the global logic of neoliberalism and responds to a common charge levied against OWS: that its programme was overly diffuse. Building on Harvey's work, I speculate that perhaps, on the contrary, diffuse social movements may be the only way to contend with the all-encompassing, ectoplasmic manifestation of market logic.

While the first piece meditates on diffuse and shifting ideologies, the second piece focuses narrowly on one hard and fast fulcrum of social being, the human body, which - no matter how endlessly malleable it may seem, or the variety of race, class and gender lenses through which it may be interpreted - manages to communicate both presence and vulnerability across a multitude of contexts. This second piece considers the Québec Student Strikes in light of Giroux's unders- 
tanding of human disposability, which in the U.S. is facilitated by the removal of large numbers of human bodies from sight: namely, the bodies of young African American men who are in prison. In an era of Internet everything, when we are losing touch with others' physical presence, it may well have been the sight of so many young bodies under attack during the Québec Student Strikes (a sight ironically transmitted largely via the web) that catalyzed sympathy for protestors and their cause.

If the first piece grapples with diffuse, macro-level ideologies and the second meditates on the concrete instance of the human body, the third and final piece lingers at the "in-between" level of social ontology: the institutions that link bodies and ideologies through spaces, standards, and regimes. Specifically, the third piece considers the effect of the Québec Student Strikes on academia. Giroux views the Occupy movement as having opened new spaces of intellectual and educational engagement. In a somewhat less optimistic vein, this essay suggests that the space of radical pedagogy tends to collapse when lessons move from the street back to the lecture hall, where traditional and hierarchical social relations are automatically reasserted.

There is no conclusion. The article makes no attempt, for instance, to draw lessons concerning the new face of social movements and their efficacy or lack thereof. For one thing, it seems to me extremely premature to render judgment on the protest movements of 2012. Occupy continues to make its presence known in scattered bursts, offering a loose and endlessly adaptable template for social action. For instance, one of the ongoing responses to the suffering caused by Hurricane Sandy on the U.S. East Coast is Occupy Sandy, which attempts to practice relief work along new lines, building social solidarity as it provides aid (Occupy Sandy Recovery, 2013). And as events from summer 2013 in Egypt attest, we will be watching the fruits of the Arab Spring develop for a long time to come, with no certainty as to their sweetness. Rather than drawing broad conclusions, therefore, the present article works toward a far more modest goal: to convey certain intimations of the possibility for large-scale change-and certain grave doubts about that possibility-which arose at the intersection of radical student action and one graduate student's radical readings.

\section{OVERTURNING THE COMMON SENSE OF CAPITALISM: OCCUPY WALL STREET AND THE POLITICS OF DIFFUSION}

Occupy Wall Street and the ensuing Occupy movements were roundly criticized for having no well-articulated goals (Naison, 2011). Given the significant number of issues the Occupy movement tackled as it spread, it might equally have been critiqued as having too many well-articulated goals. However, writing well before OWS, David Harvey set a framework for understanding why any protest movement in the age of neoliberalism may have to be amorphous and ill-defined in order to survive. This is because neoliberal philosophy, which underwrites the perpetuation of our current market systems ${ }^{1}$, is itself amorphous and, in many respects, ill-defined (Harvey, 2007).

1. The term neoliberalism has been used in a variety of ways, across various periods. As discussed here, Harvey uses neoliberalism to refer to a Reaganite/Thatcherite brand of free market boosterism, based primarily on the work of Milton Friedman. 
According to Harvey, "Neoliberalism has become a hegemonic discourse with pervasive effects on ways of thought and political-economic practices to the point where it is now part of the commonsense way we interpret, live in, and understand the world" (Harvey, 2007: 22). In saying this, Harvey helps to elucidate the fact that neoliberal thinking does not have to embody one systematic or coherent line of logic in order to perpetuate itself. One of the hallmarks of commonsense understanding is that its various strands can conflict with one another without seeming to invalidate one another, or the commonsense whole. Consider, for instance, the contradictions that arise between oft-cited bits of wisdom such as "absence makes the heart grow fonder" and "out of sight, out of mind." We invoke each as the occasion warrants, as commonsensically true, without the common sense of love being called into question. What holds commonsense together is a belief that its precepts simply fit, simply "make sense" - so that whatever position we adopt within it feels coherent at the moment.

Neoliberal discourse has come to function in an analogous way. Neoliberal economics had fairly precise beginnings in the thinking of University of Chicago economists (Harvey, 2007: 26), and its core tenets can be described in a fairly straightforward manner. They include the idea that markets function best when unfettered by the state; that, left to do their work, entrepreneurs will lead humans to better decisions and outcomes than will collective deliberations ; that private property and individual liberty are cornerstones of well-functioning markets ; and that the primary role of the state should be "to create and preserve an institutional framework appropriate to such practices," and no more than that (Harvey, 2007: 22-23).

However, the politics identified with contemporary neoliberal discourse do not by any means always accord with these central tenets. For instance, dissenters are often silenced in neoliberal regimes, which would seem to run counter to the idea that personal liberty is paramount to a healthy nation. States step in to bail out ailing industries, often in the form of direct subsidies, trade protections, or the use of land or other resources at below-market rates. This would seem to run counter to the idea of a free market, in which companies are supposed to live and die by the value of what they have to offer without assistance from the state.

The commonsensical whole manages, nevertheless, to cohere due to a deft sort of shell game. When the economy is strong, its strength is assumed to reflect the soundness of neoliberal reliance on markets. When the economy is weak, governmental and corporate advocates explain away anti-neoliberal policies such as subsidies by suggesting these policies are needed to protect the markets, which are the cornerstone neoliberal economics and hence necessary to restoring the strength of the economy.

In "Neoliberalism as Creative Destruction," Harvey helps us to understand that the internal contradictions of neoliberalism will never, in and of themselves, spur the rejection of the framework. This is for two major reasons. First, neoliberalism has been naturalized, so that it occurs to us as an a priori set of ideas that simply reflect what is true or real, without having to be questioned. Harvey argues that this naturalization has occurred in no small part because of the way that neoliberals have leveraged references to freedom and liberty, concepts that encourage commitment and buyin across broad political and socioeconomic spectra (Harvey, 2007: 25). 
Second, argues Harvey, neoliberalism is not simply a philosophy, but a tool for the assertion and consolidation of class privilege (Harvey, 2007: 27). Understanding this makes it easier to understand why and how neoliberalism does not always have to adhere to its own logic. It is not simply "about" principles, but about the struggle of powerful groups to maintain power. Among other things, such drive to maintain power underwrites imperial expansions of neoliberal frameworks through force, as in Chile in the 1970s, and Iraq in the new millennium (Harvey, 2007: 28, 25). Even if achieved by force, the extension of neoliberalism serves, ironically, to make it appear inevitable. As it is extended, its reach seems ever more global, ineluctable and complete. The same principle was at work in the "shock therapy" approach to economic reform in Russia and Eastern Europe in the 1990s, which extended neoliberal logic to former communist bloc states, sealing a sense of inevitability (Harvey, 2007: 28).

The total reach of neoliberal ideology, which allows it to survive its own internal contradictions, makes it particularly difficult to confront. Every aspect of it that you critique appears to have a rational explanation, even if its parts do not logically cohere, and even if it does not ultimately serve

broad populations in the ways they want and expect. As Žižek notes concerning shock therapy, the populations of Eastern Europe were left feeling that they "wanted freedom and democracy without corruption and exploitation, and what they got was freedom and democracy without solidarity and justice" (Žižek, 2011: n. p.).

Given how diffuse neoliberalism is, and how well it has been assimilated into common sense, it makes a great deal of sense that the Occupy movement was also diffuse. If protesters were to single out any one policy or issue to the exclusion of others, then that issue would likely soon have been lost in the "vast tidal wave" of neoliberal ideology (Harvey, 2007: 23). However, as groups in various locations joined the movement, each voicing their own sources of dissatisfaction - jobs, bailouts, debt, educational cuts, austerity measures, repressive police tactics, etc. - a mosaic of dissatisfaction was slowly assembled. It remains to be seen whether that mosaic is still being built, and at what point (if any) the cumulative picture might be stark enough to counter the commonsense assumption that neoliberalism works.

Arguably, however, before a persuasive discourse or politics can arise counter to neoliberalism, an alternative sense of things must somehow emerge.

\section{AGAINST DISPOSABILITY}

When Henry Giroux sums up what he sees of the situation of youth in America in Youth in a Suspect Society: Democracy or Disposability?, he speaks of them as being "disposable." The ultimate symbol of disposability is the American prison, where, in particular, more young black men will go than will go to college:

As the politics of the social state gives way to the biopolitics of disposability, the prison becomes a preeminently valued institution whose disciplinary practices become a model for dealing with the increasing number of young people who are considered to be the waste products of a market-mediated society. (Giroux, 2009: 82) 
When young people from low-income backgrounds are not central to the market - i.e., when there is already abundant labor, so that state and corporate interests weigh against investing in creating opportunities for them - then young people become disposable on a fundamental, bodily level. It becomes more efficient to let them languish in jail than to offer the resources needed for them to build meaningful lives.

It is tricky to move from discussions of young, primarily poor black men in prison in the United States to young people of a variety of classes and colors fighting against tuition hikes in Canada. However, Giroux's concept of disposability allows us to view the Québec Student Strikes in a different light. In Canadian media, the primary lens that was brought to the strikes at the outset was one of spoiled children: the protesters were simply over-privileged kids who wanted to get everything free from the state (Goodman, 2012: n. p.). As Professor Anna Kruzynski remarked in a Democracy Now radio interview, however:

But no one is talking anymore about spoiled children in Québec, after three months of very articulate and very well thought out argumentation around the vision of our society. . [T] his is about the privatization of our public services. It's the beginning of austerity measures, or the continuation of austerity measures. And it's not about, you know, the - it's not about spoiled children going off and taking advantage of their strike and going to Florida or whatever. This is what was said here in Québec, as well, at the beginning of the strike. And I think that now the Canadian media and media elsewhere are waking up to what's going on here... (Goodman, 2012: n. p.)

Many would say that the tide did not turn for long. Support for student protestors clearly waxed and waned. But what spurred a temporary embrace of the students' cause by broader sectors of the population? An argument could be made that it was the image, night after night, of tens and thousands of young bodies in the streets. Canadians were confronted with the specter of troops in riot gear, at times treating students much like they would if they were Syrian or Russian police confronting Occupy-type movements there: clashing with the protesters in familiar streets; charging into clusters of demonstrators, breaking students into smaller groups; pursuing them, pepper spraying them, throwing flash bang grenades and beating them with batons (CBC, 2012).

Indeed, it was the move by the Québec government to clamp down on the rallies that provoked the greatest show of support by the general public. In the wake of Bill 78, people of all ages began to flood the streets in support of the student protesters; people protested in their own neighborhoods as well, sometimes by doing things as simple as bringing out pots and pans to bang on (Goodman, 2012). Hence, on the one hand, as Professor Kruzynski pointed out, there was an increasing identification with the demands of the protestors as also representing the interests of broader populations, whose most significant needs may be trampled under austerity measures (Goodman, 2012). On the other hand, it seems that an increasing physical identification was at work, not simply an identification on the level of ideas. 
This is why Giroux's framework of human disposability is so powerful. It reminds us of the bodies of people, their vulnerabilities and needs as living, physical beings. When large populations of young black men are channeled into American prisons, part of the "double whammy" is that they are locked away, out of sight. No one, save for the guards, sees them in their cells, day after day. The sight of all those young bodies being stored, kept useless and in some senses essentially lifeless might well be enough to create dissent. But nobody sees them.

By and large the Québec had less at stake in a bodily sense than the population of young men who are funneled into prison systems. However, their determination to keep education accessible is, at its most basic level, also a determination connected with physical survival. For so many, attending university is about the ability to earn a living, to survive and thrive physically as well as emotionally and intellectually. Low tuition fees are connected to the desire to become educated without having to sacrifice basic needs in the pursuit, and without forcing families to make dire choices about where they will put their resources. In other words, ultimately, the student protesters articulated a defiance of disposability and a fierce belief in their own right to be integral human beings and human bodies, and to flourish so that they can contribute to the body politic in turn. This articulation was made real by the sight of student bodies crowded together, in all kinds of weather conditions and under the threat (and actuality) of police violence. The strikes were a reminder that none of us is disposable.

\section{THE COLLAPSE OF THE SPACE OF FREE THOUGHT IN THE ACADEMY AND ITS RADICAL RE-EXPANSION IN QUÉBEC}

There was something poignant about reading Henry Giroux's 2007 The University in Chains in the midst of the Québec student protests. Giroux's book primarily concerns American institutions of higher education, although he himself is a professor in Canada. Giroux argues that democracy depends on the vitality of education, and that this critical linkage is being lost due to the increasing presence of military-industrial interests in university life. Universities as well as individual scholars become increasingly dependent on financing from private corporations and the Pentagon. Simultaneously, right wing groups seek to silence dissent in the academy by portraying universities as bastions of leftist radicalism that are destroying the morals and the patriotism of America's youth.

The university is a prime site of the type of intellectual engagement that leads to social and political renewal. As a net result of right wing and militaristic pressures, however, the space for that type of exchange is shrinking (Giroux, 2007).

Giroux hailed the Occupy movement as having the potential to open new spaces for intellectual and educational engagement of the sort that lead to social and political renewal. In April 2012, he wrote: 
Let's hope that as time unfolds and new spaces emerge, the Occupy movement and others engage in a form of borderless pedagogy in which they willingly and assertively join in the battle over ideas, reclaim the importance of critique, develop a discourse of hope and occupy many quarters and sites so as to drown out the corporate funded ignorance and political ideologies that strip history of its meaning, undermine intellectual engagement and engage in a never-ending pedagogy of deflection and disappearance. (Giroux, 2012: n. p.)

Perhaps nowhere did we see a new space open and expand so rapidly as in Québec, where student protests over tuition hikes rapidly grew into a significant movement that involved labour interests and people of various generations (Christoff, 2012: n. p.), and which created something of a national crisis for the Charest government (Goodman, 2012: n. p.). Indeed, when the Québec government sought to quiet the demonstrations by passing Bill 78, which imposed restrictions on the right to protest, more than 400000 people took to the streets, defending the space of radical dialog.

One of the intriguing dynamics of the protests was that they were for higher education, but they also rapidly evolved into a sphere where the students took charge of the business of social interpretation and analysis, thereby inverting the traditional dynamics of the academy. Tellingly, in one radio interview of a student leader and a professor who participated in the demonstrations, the student leader referred to the professor as her "colleague", suggesting a flattening of roles (Goodman, 2012: n. p.). When the spaces open up in which people begin to imagine new relations of power, they can overtake the carefully thought-out ideas that professors such as Giroux have for the renewal of intellectual life. Indeed, in his op-ed on the educational potential for the Occupy movement cited above, Giroux seemed to hang on dearly to the idea that public intellectuals such as himself would find their way in as the "models" of thought and action:

It is precisely through the broad mobilization of traditional and new educational sites that public intellectuals can do the work of resistance, engagement, policymaking and supporting a democratic politics. Such spheres should also enable young people to learn not just how to read the world critically, but to be able to produce cultural and social forms that enable shared practices and ideas rooted in a commitment to the common good. Such spheres provide a sense of solidarity, encourage intellectuals to take risks and model what it means to engage a larger public . . . (Giroux, 2012: п. p.)

Ultimately, then, Giroux's call for a "borderless pedagogy", certain important borders and boundaries remain (Giroux, 2012: n. p.). Public intellectuals, in Giroux's take, are the ones who will "do the work." Just as in the classroom, the young people will learn, while public intellectuals "model what it means to engage a larger public" (Giroux, 2012: n. p.). The irony of Giroux's vision, of course, is that in Québec, the students were the ones doing the work of resistance, engagement and policymaking. They were reading the world critically for themselves, asserting their own central role in modeling change and engaging a larger public.

This is by no means to belittle Giroux's critique of academia or his hopes for the Occupy movement. Nor is it to imply that, at the close of the Printemps érable, students should have refused to follow their professors back into the classroom. After all, the primary goal of the student protesters was to enable university life to continue, which implies continuing to learn from intellectuals in the 
classroom. However, there are intriguing tensions at work, and it is not far-fetched to speculate that new tensions as well as new alliances began to form when students returned to the classroom. Particularly in courses on social movements and social theory, students who participated in the Printemps érable now possess their own autonomous basis for identifying the dynamics of change. Hopefully there are intellectuals among us who, even now, are studying how the dynamics of university life have changed - if at all - in the wake of the strikes, and whether and how critical intellectuals within the academy were able to accept student protesters as individuals who not only learn from them, but model social change for them. 
CBC. "Montreal Student Protest Ends with 122 Arrests." CBC. 17 May 2012. Web. 1 June 2012.

Christoff, Stefan. "Quebec students ignite the popular imagination." Rabble.ca. 30 Apr. 2012. Web. 1 June 2012.

Garland, Eric. "How Quebec's 'Maple Spring' Protests Fit With the Arab Spring and Occupy Wall Street (Sort Of)." The Atlantic. 12 June 2012. Web. 8 Oct. 2013.

Giroux, Henry A. "Gated Intellectuals and Ignorance in Political Life: Toward a Borderless Pedagogy in the Occupy Movement." Truthout. 20 March 2012. Web. 1 June 2012.

---. Youth in a Suspect Society: Democracy or Disposability? New York: Palgrave, 2009. Print.

---. The University in Chains: Confronting the Military-Industrial-Academic Complex. Boulder, CO: Paradigm Publishers, 2007. Print.

Goodman, Amy. "Maple Spring: Nearly 1,000 Arrested as Mass Quebec Student Strike Passes 100th Day." Interview with Gabriel Nadeau-Dubois and Anna Kruzynski. Democracy Now. 25 May 2012. Web. 1 June 2012.

Harvey, David. "Neoliberalism as Creative Destruction." The ANNALS of the American Academy of Political and Social Science 610 (2007): 21-44. Print.

Naison, Mark. "What Occupy Wall Street Has Accomplished in Two Short Months." LaProgressive. 2011. Web. 1 June 2012.

Occupy Sandy Recovery. OccupySMS, 2013. Web. 9 Oct. 2013.

Žižek, Slavoj. "Occupy Wall Street: What is to be done next?" The Guardian. 24 April 2011. Web. 1 June 2012. 